\section{Romania takes a firm line on chemical waste}

\section{London}

SENIOR Romanian officials have been disciplined over the illegal dumping of chemical waste. Several people have been dismissed, including Foreign Trade Minister Ilie Vaduva, Stefan Birlea, the chairman of the State Planning Committee, and a Secretary of State at the Foreign Trade Ministry, Constantin Stanca. Three deputy prime ministers, the Minister of the Interior, the Minister of Finance and the Minister of the Petroleum Industry have received public reprimands or warnings. The director of the free port of Sulina and the Chimica Bucharest Company, and several executive officials of these organizations have been dismissed and now face prosecution.

The waste, described officially as "chemical and petrochemical residues", which are unofficially reported to have contained polychlorinated biphenyls, was transported to Romania in three shiploads of 800 tonnes each by Italian vessels. The contract covering the shipment was, however, made with a company registered in Liechtenstein, Chimica Liechtenstein. The import of hazardous material without proper safeguards if forbidden under Romanian law. Nevertheless, according to the official Romanian media, the administration of the free port of Sulina at the mouth of the Danube signed a contract in 1986 with Chimica Liechtenstein entitling the latter to import and deposit hazardous wastes at Sulina, thereby "abusing the special status" of the free port.

In 1987, the Romanian Foreign Trade company Chimica Bucharest also concluded a contract with the Liechtenstein company, with the intention, it is said, of "utilizing" the wastes. The officials concerned were either actively concerned in the deal, or else failed to notice what was going on, or, if they did notice it, failed to to take appropriate measures.

The matter is being dealt with at the highest possible level — the dismissals were first announced during a session of the executive committee of the Romanian Communist Party, chaired by General Secretary Nicolae Ceaucescu in person. Neither Ceaucescu nor the Romanian authorities are noted for their concern over environmental matters. During the past few months, there have been protests from inhabitants of Ruse, just inside Bulgaria, about chemical fumes pouring in from Romania. Indeed, Romanian media commenting on the dumping affair concentrate more on the illegality (and implied corruption) than on the actual or potential danger.

Vera Rich

\title{
Genentech gets patent protection for tissue plasminogen activator
}

\section{Washington}

GENENTECH, the only US company approved to sell the blood-clot dissolving drug, tissue plasminogen activator (TPA), now has patent protection for its product. Genentech holds the exclusive licence to the US patent granted last week to the Belgian technology company Innovi, patent agent for the University of Leuven.

The new patent is based on work done by Désiré Collen, at the University of Leuven. The patent is reported to be a broad "composition of matter" patent covering purified TPA itself, whether it is produced by recombinant means or by isolation from normal tissue.

Based on the patent's claims, Genentech has filed suits in the United States against both Burroughs Wellcome - the US division of the UK company Wellcome plc - and the Massachusetts biotechnology company Genetics Institute. The two companies are collaborating to produce their own version of TPA, and are expected to request approval some time this year to sell it in the United States.

Genentech is also currently embroiled in three other lawsuits over TPA. It has been sued by Abbott Laboratories in the United States for infringing a patent held by Abbott on a class of blood-clot dissolvers, and its Japanese patent is also being hotly contested by several companies in Japan (Nature 333, 587; 1988).

Meanwhile, the company's appeal against the decision that its UK patent is invalid is being heard in the UK high court. Genentech will be arguing its case for reinstatement of the patent, which was successfully challenged by Wellcome last year, and ruled to be too broad to stand.
The three appeal court judges are being advised on scientific matters by Dr Sydney Brenner, director of the MRC Molecular Genetics Unit in Cambridge. A decision is not likely for several months and, whatever, it is likely to be appealed.

The new patent granted to Innovi does not preclude the US patent office from granting additional patents for TPA. Companies, including Genentech, are seeking other, perhaps more specific, patents covering various forms of TPA and processes for making it.

Genentech will have to fight hard to establish and maintain patents that will give it sufficient means to stave off competitors developing TPA products. Numerous companies are working on "second-generation" forms of TPA that are improvements on the naturally occurring molecule, and it will not be clear what degree of protection the Innovi patent gives to Genentech until more infringement cases are settled in court. The effect on Genentech of the patent granted to the University of Oxford several weeks ago covering purified natural TPA with various sugar sidechains is also still uncertain (Nature 333, 383; 1988).

But Genentech is still the only company in the United States with approval to sell TPA, and its heaviest competition now comes from streptokinase, which is sold by Hoechst-Roussel and SmithKline Beckman for one-tenth of the $\$ 2,200$ price that Genentech charges for a single dose of TPA. To counter claims that its price is unfair, Genentech announced last week uninsured heart-attack patients will not be charged for the drug if they earn less than $\$ 25,000$ per year

Carol Ezzell

\section{Human Frontiers gets a mention in Toronto}

\section{Tokyo}

JAPANESE government officials in charge of the Human Frontiers Science Program are delighted that the programme was mentioned, albeit briefly, in the economic declaration of the summit of Western nations held last week in Toronto.

Japanese Prime Minister Noboru Takeshita brought up Frontiers at a working dinner on 20 June. He said that "until now Japan has imported the results of basic research, but from now on we want to export".

He pledged to follow in the footsteps of former Prime Minister Yasuhiro Nakasone and continue to promote the programme, and asked for the cooperation of the other summit nations. "The whole world will benefit from the promotion of science", he said.
It was touch-and-go whether Frontiers would be mentioned in the declaration, as economic and agricultural issues dominated the summit and environmental problems stole the scientific limelight. But in the end it was included under "other issues". The declaration noted the successful conclusion of the feasibility study of the programme, thanked Japan for providing summit nation scientists with the opportunity to contribute to the study and looked forward to the Japanese government's proposal for implementation of the programme "in the near future".

The declaration will provide a powerful bargaining tool when the Science and Technology Agency and Ministry of International Trade and Industry negotiate with the Ministry of Finance for funds for Frontiers later this year. David Swinbanks 